\title{
Dyplomaci i politycy sowieccy w Kartach Informacyjnych poselstwa RP w Moskwie (rok 1927)
}

bieranie informacji przez służby państwowe na temat różnych osób
było i jest sprawą dość oczywistą. Z punktu widzenia badań nad historią polskiej dyplomacji interesuje nas proces zbierania i wykorzystywania tych informacji. Andrzej Pepłoński chyba jako pierwszy zwrócił uwagę na dokumentację dyplomatyczną znajdującą się w Archiwum Akt Nowych, ilustrującą stan wiedzy polskich dyplomatów i Ministerstwa Spraw Zagranicznych na temat różnych osobistości ze świata polityki i dyplomacji. Pisze on, że centrala MSZ zobowiązała placówki zagraniczne do przesyłania „raportów o miejscowym korpusie dyplomatycznym”. W tym celu wprowadzono specjalne karty informacyjne zawierające dane na temat pracy zawodowej tych osób, ich poglądów politycznych, zainteresowań, cech charakteru $^{1}$. Materiały te wykorzystał także w niewielkim stopniu Marcin Kruszyński ${ }^{2}$ oraz pisząca te słowa ${ }^{3}$.

Polskie Ministerstwo Spraw Zagranicznych w okresie międzywojennym posiadało najprawdopodobniej ogromną dokumentację biogramów nie tylko dyplomatów z innych państw, ale także osób ze świata polityki, gospodarki, wojskowości i być może innych dziedzin. Dokumentacja przechowywana w Archiwum Akt Nowych stanowi zapewne tylko niewielki fragment materiałów informacyjnych gromadzonych przez MSZ.

A. Pepłoński Wywiad a dyplomacja II Rzeczypospolitej, Torun 2004, s. 110.

2 M. Kruszyński, Ambasada RP w Moskwie 1921-1939, Warszawa 2010, s. 125-126.

3 M. Gmurczyk-Wrońska, Stanisław Patek. Raporty i korespondencja z Moskwy (1927-1932), wyd. I, Warszawa 2010, wyd. II, Warszawa 2013; Stanisław Patek $w$ dyplomacji i polityce (1914-1939), Warszawa 2013. 
Analiza tej dokumentacji, zawierającej niezwykle bogate informacje, jest niewątpliwie frapująca $z$ badawczego punktu widzenia. Dokumenty te inspirują do stawiania przede wszystkim pytań związanych z pracą i funkcjonowaniem polskiej dyplomacji, ale także o to, gdzie znajduje się komplet tych dokumentów i czy w ogóle się zachował. W artykule zostanie uwzględniony niewielki tylko fragment dokumentacji wytworzonej przez poselstwo RP w Moskwie w 1927 r.

Nie wiemy, kto w MSZ był pomysłodawcą zbierania informacji na temat ważnych osobowości z różnych państw i tworzenia otwartej kartoteki osobowej, czyli uzupełnianej systematycznie w zależności od pełnionych przez te osoby funkcji. System ten jednak funkcjonował już na pewno pod koniec 1926 r. Możemy nawet przypuszczać, że powstał on właśnie w tym czasie. Być może należy to wiązać ze zmianami w MSZ po przewrocie majowym, ale nie można wykluczyć, że proces zbierania informacji funkcjonował dużo wcześniej, a po 1926 r. został jedynie zintensyfikowany. Przypomnijmy, że poza zmianami personalnymi, a szczególnie objęciem funkcji ministra spraw zagranicznych przez Augusta Zaleskiego, niewielkiej reorganizacji uległy także struktury w ministerstwie. W kontekście omawianej tematyki najważniejszy był Departament Polityczno-Ekonomiczny. Został on tak nazwany po połączeniu spraw politycznych z ekonomicznymi i włączeniu doń Wydziału Ekonomicznego (sprawy gospodarcze włączono do poszczególnych wydziałów dyplomatycznych). W skład Departamentu wchodziły następujące wydziały: Organizacji Międzynarodowych (P I), Zachodni (P II), Wschodni (P III), Prasy (P IV), Traktatowy $(\mathrm{P} \mathrm{V})^{4}$. Departament Polityczno-Ekonomiczny podlegał wprawdzie Gabinetowi Ministra, ale do czasu objęcia przez Józefa Becka funkcji ministra spraw zagranicznych odgrywał jedną z najważniejszych ról w strukturach MSZ. Po 1932 r. jego znaczenie uległo zmniejszeniu na rzecz Gabinetu Ministra. Zapewne po 1932 r. to Gabinetowi podlegały sprawy kart informacyjnych. Od 13 czerwca 1926 do 31 stycznia 1929 r. na czele Departamentu Polityczno-Ekonomicznego (po odejściu Juliusza Łukasiewicza) stał Tadeusz Jackowski ${ }^{5}$, nie wiemy jednak, czy to on był inicjatorem tworzenia w MSZ kart informacyjnych. W korespondencji pomiędzy Dyrekcją Departamentu Politycznego MSZ (czyli Departamentu Polityczno-Ekonomicznego, w dokumentacji występuje nazwa Departament Po-

4 Szerzej J. Łaptos, Dyplomaci II RP w świetle raportów Quai d'Orsay, Warszawa 1993, rozdział Organizacja i personel polskiego Ministerstwa Spraw Zagranicznych, s. 21.

5 Tadeusz Gustaw Jackowski pełnił do 1926 r. funkcję radcy poselstwa w Berlinie. W 1. 1929-1937 był posłem w Brukseli. Pozostawił wspomnienia $W$ walce o polskość, Kraków 1972. We wspomnieniach nie podaje żadnych informacji na temat Kart Informacyjnych. 
lityczny) a poselstwem w Moskwie przywoływana jest często instrukcja DDP 1/26/Inf. z 20 XII 1926 r. dotycząca opracowywania kart informacyjnych ${ }^{6}$. W Archiwum Akt Nowych w zespołach z poszczególnych placówek dyplomatycznych i w Ministerstwie Spraw Zagranicznych występuje dość znaczny materiał dokumentacyjny dający wgląd w ten proces. Praca nad biogramami, czyli kartami informacyjnymi poszczególnych osób, przebiegała dwutorowo: na placówkach dyplomatycznych i w centrali, czyli w Departamencie Politycznym. Karty te miały charakter otwarty, to znaczy, że były uzupełniane przez centralę, ale przede wszystkim przez placówki dyplomatyczne i to one włączały je do Skorowidza Informacyjnego. Formularze kart i obwoluty do nich były prawdopodobnie drukowane w Warszawie, gdyż przykładowo poselstwo w Moskwie zwracało się do centrali o przysłanie ich?

Placówki wymieniały się także informacjami na temat poszczególnych osób, wysyłały również kopie opracowanych już biogramów zainteresowanym placówkom. Przykładowo poselstwo w Moskwie wysyłało kopie kart francuskich dyplomatów w Moskwie do polskiej ambasady w Paryżu․ Kiedy do Moskwy w 1931 r. po wyjeździe ambasadora Jeana Herbette'a przyjechał nowy ambasador François Dejean, poselstwo w Moskwie prosiło DDP o nadesłanie odpisów kart informacyjnych tego dyplomaty ${ }^{9}$. Dodatkowo DDP wysyłało pisma do innych placówek dyplomatycznych, prosząc o dane na temat poszczególnych osób. Przykładowo w grudniu 1927 r. wysłano pismo do poselstwa w Sztokholmie, prosząc o informacje na temat Waleriana Dowgalewskiego, nowo mianowanego ambasadora ZSRR w Paryżu, szczególnie na temat jego stosunku do Polski ${ }^{10}$. Dodajmy, że wcześniej, bo już w listopadzie, sekretarz ambasady polskiej w Paryżu Feliks Frankowski przesłał do centrali kartę informacyjną na temat Do-

6 Nie udało się odnaleźć tej instrukcji. Poselstwo w Moskwie powołuje się na datę 20 XII 1926 r. i podaje (w różnych pismach) numery Nr DDP. 1/26/Inf. z 20 XII 1926 r. lub 1/22/ /Inf. z 20 XII 1926 r. Należy przypuszczać, że chodzi o tę samą instrukcję, tylko poselstwo myliło numery.

7 AAN, MSZ, sygn. 122a, k. 195, Moskwa 1 XI 1932, pismo podpisane przez radcę Jana Karszo-Siedleckiego do MSZ A.III.

8 AAN, MSZ, sygn. 122a, k. 69, Moskwa, 27 II 1928, pismo chargé d'affaires Zielezińskiego do DDP MSZ z informacją o wysłaniu do Paryża kopi kart ambasadora Francji w Moskwie Jeana Herbette'a, Arensa i Jeana Helleu.

9 AAN, MSZ, sygn. 122a, k. 138, Moskwa 21 VII 1931, pismo Patka do DDP MSZ.

10 AAN, MSZ, sygn. 122a, k. 54, Warszawa 7 XII 1927, pismo z DDP z podpisem Tadeusza Jackowskiego do poselstwa w Szkokholmie. 
wgalewskiego ${ }^{11}$. Także poselstwo w Tokio wysłało do Warszawy informacje na jego temat ${ }^{12}$.

W październiku 1932 r. poselstwo w Moskwie pisało do centrali: „Poselstwo zawiadamia, że w toku prac nad rewizją swego Skorowidza Inform. uwzględniło również karty informacyjne działaczy sowieckich otrzymanych bądź z Konsulatów R.P. w Tyflisie i Charkowie bądź też i z innych źródeł" "13. Nie wiemy, czy po tym likwidowano starą kartę i zachowywano aktualną, czy pozostawały wszystkie wersje, czy więc dana osoba posiadała tylko kartę, czy coś w rodzaju teczki. Pod koniec grudnia 1933 r. wicedyrektor Gabinetu ministra Becka Seweryn Sokołowski pisał do polskich przedstawicielstw dyplomatycznych: „Powołując się na część V-tą instrukcji w sprawie Skorowidza Informacyjnego z dn. 31. I. 1929 r. Nr. DDP. Inf. 295/28 - przypominam, że Urzędy Zagraniczne obowiązane są nadsyłać Ministerstwu najpóźniej do końca stycznia każdego roku raport o Korpusie Dyplomatycznym"14.

Poselstwo w Moskwie wysyłało systematycznie karty do centrali. W DDP były one uzupełniane i modyfikowane, najczęściej stylistycznie, i ponownie wysyłane do Moskwy ${ }^{15}$. Jak już wspomniano, poselstwo w Moskwie otrzymało instrukcję z DDP 20 XII 1926 r. na temat opracowywania kart informacyjnych. Poselstwo 22 lutego 1927 r. przesłało do Warszawy 9 kart z następującymi nazwiskami: Maksima Litwinowa, Lwa Karachana, Borisa Stomoniakowa, Siemiona Arałowa, Fiodora Rotsztejna, Mieczysława Łoganowskiego, Klimienta Woroszyłowa, Józefa Unszlichta, Michaiła Tuchaczewskiego ${ }^{16}$. Następnego dnia wysłano kolejnych 10 z nazwiskami Gieorgija Cziczerina, Borisa Steina, Michaiła Karskiego, Dymitra Floriańskiego, Andrzeja Sabanina, Sergjusza Dmitrjewskiego, Michaiła Ka-

11 AAN, MSZ, sygn. 122a, k. 56, Paryż 26 XI 1927, pismo Frankowskiego do DDP.

12 AAN, MSZ, sygn. 122a, k. 60, Tokio 9 XI 1927, pismo rady Frylinga do DDP.

13 AAN, MSZ, sygn. 122a, k. 188, Moskwa 26 X 1932, pismo podpisane przez Jana Karszo-Siedleckiego do MSZ DDP.

14 AAN, MSZ, sygn, 122, k. 5, Warszawa 14 XII 1933, pismo Sokołowskiego do kierowników urzędów dyplomatycznych.

15 AAN, MSZ, sygn. 122a, k. 17, Warszawa 24 III 1927, pismo dyrektora DDP do Patka z informacją, że wysyłają do Moskwy karty kilkudziesięciu osób.

16 AAN, MSZ, Gabinet Ministra, Raporty i informacje o wyższych urzędnikach i korpusie dyplomatycznym w ZSRR 1927-1933, sygn. 122 a, Moskwa, 22 II 1927, k. 6, pismo Patka do Dyrekcji Spraw Politycznych. Nie udało się odnaleźć instrukcji Nr DDP. 1/26/Inf. z 20 XII 1926 r. Patek pisze, iż taką poselstwo otrzymało. Biogramy tych osób w AAN, Ambasada RP w Moskwie, sygn. 36, k. 5-13. 
linina, Aleksieja Rykowa, Sergo Ordżonikidze, Anastasa Mikojana ${ }^{17}$. Po otrzymaniu pierwszej partii w zastępstwie Dyrektora Departamentu Politycznego dyrektor Gabinetu Ministra i Protokołu Dyplomatycznego Stefan Przeździecki 24 lutego 1927 r. pisał do posła w Moskwie Stanisława Patka: „Ministerstwo Spraw Zagranicznych potwierdza niniejszym odbiór 9 kart informacyjnych [...] M.S.Z. prosi o kontynuowanie pracy nad skorowidzem przesuwając jednocześnie termin nadesłania pierwszej serji kart do dn. 15 marca r.b. Jednocześnie zaznacza się, że numeracja kart jest prowadzona oddzielnie w Centrali i osobno na placówkach tak, że numeru porządkowego w kartach nie należy wypełniać. Na wypadek potrzeby poinformowania się o charakterystykach wybitnych działaczy politycznych lub uzupełnienia danych, jakie inne placówki polskie mogłyby nadesłać w stosunku do różnych osobistości sowieckich, M.S.Z. zaznacza, że informacje tego rodzaju są skoncentrowane w Dyrekcji Departamentu Politycznego i mogą być przesłane w razie zapotrzebowania dla skompletowania danych posiadanych przez poselstwo" 18 .

Wzór karty informacyjnej powstał zapewne w MSZ. Nie wiemy, czy były one jednakowe dla wszystkich placówek. Poselstwo w Moskwie posługiwało się kartami informacyjnymi obejmującymi następujące informacje: 1. Imię i nazwisko; 2. Dane biograficzne; 3. Przynależność partyjna: (środowisko specjalnych wpływów); 4. Charakterystyka: (m.in. stopień niezależności materialnej, związki ze sferami gospodarczymi i z poszczególnymi osobistościami); 5. Stosunek do Polski (m.in. Polacy, z którymi pozostawał w bliższych kontakcie); 6. Stosunek do innych państw: (zwłaszcza Francji, Anglii, Niemiec i ZSRR); 7. Specjalne stosunki z organami prasy; 8 . Varia ${ }^{19}$.

Podane poniżej biogramy zawierają często, chociaż nie zawsze, taki podział i numerację.

Zaprezentowane biogramy 7 dyplomatów i polityków sowieckich stanowią fragment dokumentacji znajdującej się w AAN w zespole Ambasada RP w Moskwie, sygn. 36. Biogramy te opracowano najprawdopodobniej w 1927 r. Poza kilkoma dokumentami nie podano dat ich opracowania. W teczce tej na kartach 5-53 przedstawiono biogramy 48 osób, w tym

17 AAN, MSZ, Gabinet Ministra, Raporty i informacje o wyższych urzędnikach i korpusie dyplomatycznym w ZSRR 1927-1933, sygn. 122 a, Moskwa, 23 II 1927, k. 10, pismo Patka do Dyrekcji Spraw Politycznych. Biogramy tych osób w AAN, Ambasada RP w Moskwie, sygn. 36, k. 14-

18 AAN, MSZ, Gabinet Ministra, Raporty i informacje o wyższych urzędnikach i korpusie dyplomatycznym w ZSRR 1927-1933, sygn. 122 a, Warszawa 24 II 1927, k. 5-6, pismo Przeździeckiego do Patka.

19 AAN, Poselstwo RP w Moskwie, sygn. 36, k. 43-44. Wzory kart informacyjnych. 
głównie dyplomatów i polityków, ale także wojskowych, osób powiązanych z gospodarką. Wybór $7 \mathrm{z}$ nich wynikał ze znaczenia tych postaci dla spraw polskich i stosunków polsko-sowieckich, chociaż jest oczywiście subiektywny. W biogramach zachowano pisownię z dokumentacji. $\mathrm{Na}$ końcu każdego dokumentu dodaję swój komentarz.

Wybrane dokumenty, a przede wszystkim lektura tych zdeponowanych w Archiwum Akt Nowych, wskazują na dużą wiedzę i profesjonalizm polskiej dyplomacji w gromadzeniu danych na temat sowieckiej dyplomacji, chociaż w biogramach tych występują także braki. Ich lektura wydaje się ciekawa szczególnie w kontekście publikacji historycznych na temat stosunków polsko-sowieckich, polskiej i sowieckiej dyplomacji i polityki zagraniczneje ${ }^{20}$.

\section{Małgorzata Gmurczyk-Wrońska}

20 Wymieniam ważniejsze pozycje: M. Wołos, O Pitsudskim, Dmowskim i zamachu majowym. Dyplomacja sowiecka wobec Polski w okresie kryzysu politycznego 1925-1926, Kraków 2013; idem, Francja-ZSRR. Stosunki polityczne w latach 1924-1932, Toruń 2004; W. Materski, Bolszewicy i samuraje. Walka dyplomatyczna i zbrojna o rosyjski Daleki Wschód (1917-1925), Warszawa 1990; idem, Georgia rediviva. Republika Gruzińska w stosunkach międzynarodowych 1918-1921, Warszawa 1994; idem, Na widecie. II Rzeczpospolita wobec Sowietów 1918-1943, Warszawa 2006; idem, Pobocza dyplomacji. Wymiana więźniów politycznych pomiędzy II Rzeczapospolita a Sowietami $w$ okresie międzywojennym, Warszawa 2002; idem, Tarcza Europy: stosunki polsko-sowieckie 1918-1939, Warszawa 1994; E. Duraczyński, Stalin. Twórca i dyktator supermocarstwa, Pułtusk-Warszawa 2012; A. Pepłoński, Wywiad a dyplomacja II Rzeczypospolitej, Toruń 2004; M. Kruszyński, Ambasada RP w Moskwie 1921-1939, Warszawa 2010; M. Gmurczyk-Wrońska, Stanisław Patek. Raporty i korespondencja z Moskwy (1927-1932), wyd. I, Warszawa 2010, wyd. II, Warszawa 2013; idem, Stanistaw Patek w dyplomacji i polityce (1914-1939), Warszawa 2013; M. Kornat, Polska szkoła sowietologiczna 1930-1939, Kraków 2003; eadem, Posłowie i ambasadorzy polscy w Związu Sowieckim (1921-1939 i 1941-1943), „Polski Przegląd Dyplomatyczny”, t. 4 (2004), nr 5(21), s. 129-203; eadem, Ruch prometejski - ważne doświadczenie polityki zagranicznej II Rzeczypospolitej, „Nowa Europa Wschodnia”, 2008, nr 2, s. 76-86; Stanistaw Patek i początki jego misji w Moskwie w r. 1927 (w świetle nowych dokumentów), „Zeszyty Historyczne", z. 160 (2007), s. 120-186; S. Gregorowicz, J. M. Zacharias, Polska-Zwiazek Sowiecki. Stosunki polityczne 1925-1939, Warszawa 1995; F. Dessberg, Le triangle impossible. Les relations franco-soviétiques et le facteur polonais dans les questions de sécurité en Europe (1924-1935), Bruxelles 2009; G.-H. Soutou, La France, l'URSS et l'ere de Locarno 1924-1929, [in:] L'URSS et l'Europe dans les années 20, red. M. Narinski, E. du Réau, G.-H. Soutou, A. Tchoubarian, Paris 2000; O. V. Babenko, Pol'sko-sovetskie otnošeniâ v 1924-1928 gg.: ot protivostoâniâ k sotrudničestvu, Moskva 2007; O. N. Ken, „Alarm wojenny” wiosna 1930 a stosunki polsko-sowieckie, „Studia z Dziejów Rosji i Europy Środkowo-Wschodniej", 35(2000), s. 41-73; idem, Collective Security or Isolation? Soviet Foreign Policy and Poland, 1930-1935, St. Petersburg 1996; idem, Moskva i pakt o nenapadenii s Pol'šej (1930-1932 gg.), Sankt Peterburg 2003; O. N. Ken, A. I. Rupasov, Politburo CK VKP(b) i otnošeniâ SSSR s zapadnymi sosednimii gosudarstvami (koniec 1920-1930-h gg.). Problemy. Dokumenty. Opyt kommentariâ, čast' 1: 1928-1934, Sankt-Peterburg 2000. 


\section{Dokument 1}

k. 14 Jerzy Cziczerin, syn Wasila, od marca 1918 r. Komisarz Ludowy Spraw Zagranicznych i członek CIK'a ${ }^{21}$ ZSSR.

Ur. 1872 jako członek staroszlacheckiej rodziny Cziczerinów, kawaler; matka bar. Mejenderówna. Stryj jego Borys ${ }^{22}$ znany myśliciel rosyjski, autor rozpraw o kwestji polskiej i o Rosji w przededniu XX wieku wywierał na jego młodość dodatni wpływ. Wzrósłszy w środowisku dyplomatycznem $^{23}$, został urzędnikiem MSZ, ale w służbie tej się nie odznaczył, uchodząc pomimo wyjątkowych zdolności i zdumiewającej erudycji zarówno w rodzinie, jak i wśród kolegów za dziwaka-ideologa. Był wówczas wyznawcą idei tołstojowskich ${ }^{24}$, pociągały go również zagadnienia teologiczne, jak stosunek prawosławia do katolicyzmu. Wskutek nieporozumień z rodziną, wrodzonego romantyzmu i sympatyj rewolucyjnych znalazł się wcześnie w b. ciężkich warunkach materjalnych. Od 1905 r. członek partji przebywa długo w niedostatku na emigracji. W 1908 wydalony z Niemiec za agitację socjalistyczną, jedzie do Austrji ${ }^{25}$ i pracuje w organizacjach robotniczych. Aresztowany tamże jako rewolucjonista, powraca do Rosji dopiero w 1917.

3. W partji komunistycznej cieszy się opinją jednego z najwybitniejszych państwowych działaczy sowieckich, jakkolwiek powstały między nim a Kominternem nieraz rozdźwięki. Czynniki partyjne o zabarwieniu czysto międzynarodowem uważają jednak, że przedstawia on na stanowisku Komisarza Spr. Zagr. rewolucyjnego rządu wprost niezastąpioną siłę ze względu na prestiż wobec zagranicy. Zaufanie partji bywało narażone na szwank przez zbytnie uznanie, jakiem polityka Cziczerina cieszyła się w kołach narodow-rosyjskich oraz wśród pewnych grup emigracyjnych, nawet o łączność z któremi pomawiali Cziczerina jego polityczni antagoniści.

4. Wedle świadectwa ówczesnych swych znajomych, Cziczerin okazywał od młodu równe zainteresowanie polityką, jak filozofją, będąc wyjątkowo wrażliwym i nastrojowym. Jeszcze w okresie wojny japońskiej zakreślał wielką rolę inteligencji rosyjskiej w odrodzeniu Rosji, życząc,

21 CIK - Centralny Komitet Wykonawczy ZSRR.

22 Borys Cziczerin (1828-1904), prawnik i filozof.

23 Ojciec Gieorgija Cziczerina był dyplomatą.

24 Idee tołstojowskie, czyli tołstoizm, pojawiły się w Rosji pod koniec XIX wieku, nawiązując do poglądów polityczno-religijnych Lwa Tołstoja. W uproszczeniu można powiedzieć, że było to dążenie do przekształcenia społeczeństwa na drodze samodoskonalenia.

25 Cziczerin przebywał w Anglii i tam został aresztowany, a nie w Austrii. 
pomimo opozycyjnego stanowiska swego względem caratu, zwycięstwa armji carskiej. Z upodobania samotnik o umysłowości profesora-intelektualisty. Cziczerin żył zawsze tylko dla swoich idei, odznaczając się zupełną bezinteresownością. Jedyną jego rozrywkę stanowi świetna gra na fortepianie (którą uprawia codziennie) oraz studjum historji i literatury. Jako polityka cechuje go myślenie kategorjami państwowemi z rozmachem, właściwym szerokiej naturze rosyjskiej. Zagadnienia ekonomiczne nie pociągają go. Jego program zasadniczy: zapewnić państwu sowieckiemu mocarstwowe stanowisko /Rosyjskiego Imperjum/ 6-ta część świata/ wzmocnić wielkimi siłami rewolucji państwowość i dążenia rosyjskie, przebudzając przez zrewolucjonizowanie świadomość polityczno-narodową mas ludu rosyjskiego. Przeniesienie punktu ciężkości polityki rosyjskiej raczej na wschód niż zachód. W bieżącej polityce Cziczerin jest przebiegłym graczem dyplomatycznym starej szkoły. Z pośród współczesnych mężów stanu jest prawdopodobnie najtrudniejszym i wyjątkowo giętkim rozmówcą politycznym i negocjatorem. W pracy posiada niezwykłą wytrzymałość, która często trwa całemi nocami. Wydajność jego pracy, pomimo stałego natężenia umysłowego jest zdumiewająca i poważna choroba cukrzycy na tę wydajność ujemnie nie wpłynęła. Do ostatnich czasów nie oszczędzał sił i zdrowia, starając się koncentrować wszystkie poważniejsze sprawy w swych rękach i narzucać całemu urzędowi bezwzględny autorytet. Na kurację zagranicę jeździ niechętnie, będąc zaś na kuracji zachowuje możliwie ścisłą łączność z Komisarjatem.

5. Uważa siebie za wybitnego znawcę spraw polskich, przywykł jednak patrzeć na nie przez pryzmat dawniejszych stosunków polsko-rosyjskich, zdając sobie sprawę z historycznego obciążenia tych stosunków. Naogół nie docenia samodzielnej roli Polski w stosunkach międzynarodowych, patrząc na nią jako na teren zmagania się wpływów Wielkich Mocarstw. Stąd dążenie do pomniejszania Polski jako Mocarstwa oraz zainteresowanie jej stosunkami wewnętrznemi, celem wzmacniania w Polsce wszelkiemi sposobami i we wszystkich przejawach wpływów rosyjskich. Jako młodzieniec stykał się Cziczerin niejednokrotnie z polskimi powinowatemi matki, jeździł do Krakowa do hr. Emeryka Czapskiego, założyciela muzeum, słynnego numizmaty, żonatego z Elżbietą Meyendorffówną. Stosunki te zapisały się dodatnio w jego pamięci. Utrzymywał serdeczną korespondencję z prof. Marjanem Zdziechowskim [Wyjątki ogłoszone przez Zdziechowskiego w szkicach „Europa, Rosja, Azja”, Wilno 192326].

26 M. Zdziechowski, Jerzy Cziczerin, [in:] idem, W obliczu końca, Wilno 1937; w powojennym wydaniu Warszawa-Ząbki 1999, s. 39-42. Zdziechowski pisał głównie o Borysie Cziczerinie, którego uważał za jeden z największym umysłów w Rosji. Pisał o nim 
Nauczył się wówczas po polsku, pragnąc zgłębić polską literaturę romantyczną, zwłaszcza Słowackiego i Krasińskiego, których do dziś dnia lubi cytować.

6. Polityka Cziczerina zdaje się uparcie trwać przy nadziejach stworzenia antyangielskiego bloku kontynentalnego, obejmującego Francję, Niemcy i Rosję i przewidującego przymusowe [podkreślone w tekście M. G.-W.] wtłoczenie doń Polski [vide raport Poselstwa 750/T/26 z dn. 5.X.26]. Długie lata spędzone w Niemczech, silna domieszka krwi niemieckiej, znajomość autorów niemieckich wpłynęły na utrwalenie w jego koncepcjach polit. zasady sojuszu niemiecko-rosyjskiego, jakkolwiek z kultury i wychowania posiada pewną dla Francji życzliwość. Francja interesuje go jako mocarstwo kontynentalne. W konsekwentnym rozwoju swych tendencyj antyangielskich i wielkomocarstwowych dąży Cziczerin do aktywnej polityki na Wschodzie. Stąd pakty z państwami wschodniemi, przyjaźn z Turcją i faktyczny sojusz z rewolucją chińską.

W odniesieniu do „Prybałtyki”27 jest niewątpliwie zwolennikiem powrotu Rosji na dawne stanowiska zabezpieczające jej wyjście na morze Bałtyckie. Będzie więc praktycznie wyrazicielem naporu Rosji w kierunku morza Bałtyckiego z wyłączeniem może Finlandji, której niezawisłość nie krzyżuje planów odbudowy Wielkiej Rosji. Litwa interesuje Cziczerina jako teren porozumienia $\mathrm{z}$ Niemcami i oddziaływania tą drogą [w ten czy inny sposób] na Polskę.

Komentarz: Jest to prawdopodobnie tekst z 1927 r. W październiku 1932 r. poselstwo w Moskwie wysłało kolejna, nowa kartę Cziczerina. Pisze o tym Stanisław Patek w piśmie do MSZ DDP z 13 X 1932 r. w: AAN, MSZ, sygn. 122a, k. 186. Nie udało się odnaleźć dokumentu.

Jest to jeden z lepiej opracowanych przez poselstwo biogramów. Znakomicie uchwycono cechy Georija Cziczerina (1872-1936) jako wytrawnego i groźnego dla Polski dyplomaty. W ich opisie podziw dla jego pracy i umiejętności miesza się ze świadomościa zagrożenia dla Polski ze strony sowieckiej dyplomacji. Dobrze zostaty scharakteryzowane poglady Cziczerina na politykę zagraniczna Rosji Sowieckiej. Szczególnie cenne jest stwierdzenie, że Cziczerin, tącząc idee rewolucyjne z mocarstwowościa Rosji, dążyt do przeniesienia „punktu ciężkości polityki rosyjskiej raczej na wschód niż zachód”. Dzisiaj wiemy, że aktywna działalność dyploma-

w: Borys Cziczerin. Wspomnienia pośmiertne, „Przegląd Polski”, 1904, t. 151, z. 453; Filozofia Cziczerina, „Świat Słowiański”, 1907, nr 2, przedruk w: U epoki mesjanizmu. Nowe szkice z psychologii narodów stowiańskich, Lwów 1912; Testament Księcia Eugeniusza Trubeckiego, w: Wybór pism, Kraków 1993, s. 321-322.

27 Chodzi o Wydział Państw Nadbałtyckich i Polski. 
tyczna Cziczerina pozwoliła Rosji Sowieckiej utrzymać pozycję ważnego aktora w stosunkach międzynarodowych wtaściwie już od 1918 r. W biogramie występuja ważne informacje zwiazane z sowiecka koncepcja tworzenia antybrytyjskiego bloku kontynentalnego sktadającego się z Rosji Sowieckiej, Niemiec i Francji, mającego na celu wtaczenie do tej konstrukcji Polski i tym samym pomniejszenie roli sojuszu polsko-francuskiego, jak również pozycji Polski w stosunkach międzynarodowych. Zwrócenie przez polska dyplomację uwagi na to zagrożenie świadczy o jej wysokim profesjonalizmie w gromadzeniu i interpretacji faktów.

\section{Dokument 2}

k. 5 Maksymiljan Litwinow, syn Maksymiljana, zast. Komisarza Spraw Zagranicznych, członek Cika

Ur. w Białymstoku w 1876 r. W swoim czasie wstąpił jako ochotnik do armii carskiej i chciał się poświęcić służbie wojskowej. Rozczarowany stosunkami w wojsku zbliżył się do kół rewolucyjnych, pragnąc realizować ideały socjalistyczne. Rewolucjonista od 1893 r. Około 1900 roku zaznaczył się jako agent wywrotowego pisma „Iskra” w Rosji Południowej. W 1905 roku brał udział jako delegat organizacji ryskiej w zjeździe bolszewików. Prześladowany przez rząd carski przebywał na emigracji w Anglji, gdzie podczas wojny został aresztowany pod zarzutem szpiegostwa na rzecz Niemiec. Włada dobrze angielskim, niemieckim, słabiej francuskim. Będąc żydem, ożenił się z żydówką angielską, która należy do nielicznej grupy „oficjalnych” dam sowieckich, podtrzymujących w Moskwie stosunki towarzyskie z korpusem dyplomatycznym. Litwinow zdobył pierwsze po Cziczerinie stanowisko w Narkomindiele, usuwając innych zasłużeńszych z punktu widzenia partyjnego działaczy. Posiada markę komunisty pierwszego wojującego okresu i uchodzi za poważnego kandydata na stanowisko Komisarza Spraw Zagr. ze względu na poparcie, którym się cieszy w pewnych żydowskich i filosemickich kołach partyjnych oraz kontaktów z wpływowemi zagr. grupami żydowskiemi. Był on inicjatorem przyciągnięcia do służby NKID szeregu działaczy opozycyjnych jak Rakowskiego i Kamieniewa, których nominacje przeprowadził w ciężkich nieraz warunkach. Litwinowa charakteryzuje zdrowa umysłowość kupiecka oraz niewątpliwa inteligencja i wytrwałość. W przeciwieństwie do Cziczerina jest on człowiekiem praktycznym niezapominającym o osobistych korzyściach. Słucha on lojalnie nakazów partyjnych, ale w ramach życia sowieckiego stara się zdobyć możliwie dogodne dla siebie warunki. Uwa- 
żać go przeto można jako typowego przedstawiciela nowej burżuazji sowieckiej. Polityki osobistej nie uprawia i działa zawsze w oparciu o swój resort kładąc nacisk na zagadnienie ekonomiczne. Jego koncepcja sowieckiej polityki zagr. różni się w kilku zasadniczych punktach od Cziczerina, jakkolwiek i on posiadał zawsze wyczucie państwowych interesów rosyjskich. Zabezpieczenie przyszłości państwa sowieckiego upatrywałby, jak wielu jego komunistycznych współwyznawców, oraz członków opozycji w wytworzeniu warunków, umożliwiających poparcie rządu sowieckiego przez wielką międzynarodową finansjerę żydowską [amerykańską].

5. W stosunku do Polski nie okazywał dotąd szczególniejszego zainteresowania zagadnieniami polsko-sowieckimi i odznaczał się rezerwą w tych stosunkach. Co do polaków z którymi pozostawał w bliższym, przyjacielskim kontakcie - nie posiadamy danych.

6. Litwinow posiada powszechnie markę notorycznego germanofila, co przyznają nawet oficjalne koła niemieckie. Otrzymuje najściślejsze stosunki z Amb. Niem. w Moskwie hr. Brockdorff-Rantzau. Pociągało go stanowisko przedstawiciela sowieckiego w Londynie, kandydatura jednak natrafiła na kategoryczny sprzeciw rządu Angielskiego. Taktykę Krassina w Londynie podzielał i udzielał Krassinowi całkowitego poparcia, ceniąc go bardzo wysoko. W spr. wschodnich pozostawia politykę Karachanowi.

7. Nie wchodzą w stosunkach sowieckich

Komentarz: Jest to karta prawdopodobnie opracowana w 1927 r. W czerwcu 1932 r. poselstwo w Moskwie wysłało kolejna, nowa karte Litwinowa. Pisze o tym chargé d'affaires poselstwa w Moskwie Jan Karszo-Siedlecki w piśmie do MSZ DDP z 21 VI 1932 r. w: AAN, MSZ, sygn. 122a, k. 180. Nie udato się odnaleźć tego dokumentu.

Litwinow (1876-1951), do 1930 r. petnit funkcję zastępcy ludowego komisarza spraw zagranicznych, a potem juz komisarza spraw zagranicznych. Na uwagę zastuguje jego proniemieckość oraz różnice $w$ koncepcjach polityki zagranicznej pomiędzy nim a kierujacym do $1930 \mathrm{r}$. sowiecka dyplomacją Cziczerinem. Dzisiaj wiemy, że tak w istocie było i pracownicy poselstwa posiadali precyzyjne dane na jego temat. Zaskakuje jednak brak informacji na temat konfliktu pomiędzy tymi dyplomatami oraz, co jest bardzo ważne, brak opinii na temat antypolskiego stanowiska Litwinowa.

\section{Dokument 3}

k. 6. Lew Karachan, syn Michała, karaim, drugi zastępca Komisarza Spra. Zagr. i członek Kolegjum NKID. Ur. w Tyflisie 1889 r. ukończył 1916 uni- 
wersytet petersburski jako prawnik. Wstąpił do ros. part. soch. w 1904. W 1907 prowadził nielegalną drukarnię oraz agitację socj. w Petersburgu, Charbinie, Władywostoku. Podczas wojny członek petersburskiego Komitetu org. bolszewickiej, aresztowany, zesłany w 1915, w 1917 wszedł do WCIK oraz do Prezydjum Rady Robotniczej petersburskiej. W dniach październikowych członek Rewolucyjnego Komitetu. W listopadzie 1917 członek delegacji pokojowej do Brześcia. W lutym 1918 członek Kolegjum NKID i zast. Komisarza. Był posłem w Warszawie [1921] oraz następcą Joffego w Chinach do 1926 r., poczem objął urzędowanie w Moskwie.

Ze względu na bezpośrednią działalność rewolucyjną oraz na stosunki z wpływowemi grupami gruzińskiemi posiada mocne i poważne stanowisko w partii kom.

Odznacza się dużym temperamentem politycznym i wysoką inteligencją. Porywczy, bezwzględny, przebiegły, o dużym wyrobieniu towarzyskiem.

Z misji w Warszawie powrócił rozczarowany. Na gruncie moskiewskim odnosił się do spraw polskich w sposób rzeczowy i poprawny.

Jako ambasador w Pekinie Karachan pozostawił inną opinję na D. Wschodzie, a inną w Moskwie. Na Dal. Wschodzie uważano, że jest to karjerowicz bezwzględny, człowiek nie krępujący się niczem, nic sobie nie robiący nawet $z$ własnych poprzednio wygłaszanych opinij i przyrzeczeń, działający zarówno dobrze popularnym frazesem, jak i brutalnem przekupstwem. Stosunki z nim podtrzymywał tylko ten, kto miał w tym interes lub kto musiał i to tylko o tyle, o ile musiał. Uważano, że powodzenie jego jest względne i będzie krótkotrwałe. Tymczasem w Moskwie są przekonania, iż wywiązał się z zadania znakomicie. Ma też w Moskwie opinję zręcznego dyplomaty i wielkiego znawcy Wschodu, w stosunku do którego zajmuje decydujące stanowiskow kolegium Narkomindiełu.

Komentarz: Jest to karta prawdopodobnie opracowana w 1927 r. W czerwcu 1932 r. poselstwo w Moskwie wystało kolejna, nowa kartę Karachana. Pisze o tym chargé d'affaires poselstwa w Moskwie Jan Karszo-Siedlecki w piśmie do MSZ DDP z 21 VI 1932 r. w: MSZ, sygn. 122a, k. 180. Nie udało się odnaleźć dokumentu.

Lew Karachan (1889-1937) w 1921 r. organizowat w Polsce sowiecka placówkę dyplomatyczną. Sprawami polskimi zajmowat się szerzej w $1931 \mathrm{r}$. w czasie negocjowania z Polska paktu o nieagresji. Na uwage zastuguje fragment dotyczacy działalności dyplomatycznej Karachana na Dalekim Wschodzie, czyli w Chinach i Japonii. Jeżeli biogram pochodzi z 1927 r., to niewatpliwie wpływ na jego treść miat poset w Moskwie Stanisław Patek, 
który zetknąt się z Karachanem w Japonii. Z uwagi na znaczenie stosunków japońsko-sowieckich, ale także sowiecko-chińskich dla polskiej polityki zagranicznej Patek z niepokojem obserwowat dziatalność sowieckiego dyplomaty na Dalekim Wschodzie. Karachan byt rzeczywiście znawca problematyki wschodniej. To on doprowadzit do ponownego nawiazania stosunków dyplomatycznych Rosji Sowieckiej z Chinami oraz Japonią i podpisania stosownych porozumień.

\section{Dokument 4}

k. 7. Borys Stomoniakow, syn Spirydona, członek kolegjum NKID, kierownik spr. bałtyckich i polskich ${ }^{28}$ od kwietnia $1926 \mathrm{r}$.

Wiek około 46 lat, narodowości bułgarskiej, z zawodu inżynier technolog. Na wyższe stanowisko sowieckie wypłynął dzięki osobistym walorom i poparciu Krasina. Przed wstąpieniem do Narkomindiełu zajmował poważniejsze stanowiska w sowieckich instytucjach gospodarczych.

Będąc ideowym komunistą i człowiekiem osobiście czystym, posiada zupełne zaufanie partji.

Poselstwo pisało o nim w raporcie No. 384/T/26 z dn. 8 maja $1926 \mathrm{r}$. Stomaniakow cieszy się wśród posłów i ambasadorów zagranicznych, z którymi rokował, opinją poważnego, rzeczowego negocjatora. Osobiście jest on człowiekiem bardzo opanowanym i systematycznym, unikającym frazeologji. Posiada duże zainteresowania i znajomość zagadnień ekonomicznych. Wszelkie rokowania i sprawy ujmuje w sposób konkretny, pozostawiając na boku momenty propagandowe. Włada niemieckim i francuskim. Na stanowisku kierownika spraw polskich starał się nie zadrażniać stosunków polsko-sowieckich, kładąc specjalny nacisk na rozwój „,normalnych stosunków rzeczowych”, z Poselstwem utrzymywał poprawne nawet kurtuazyjne stosunki.

Nie miał dotąd sposobności do specjalnego ustosunkowania się do wielkich zagadnień międzynarodowych.

Komentarz: Jest to karta prawdopodobnie opracowana w 1927 r. W czerwcu 1932 r. poselstwo w Moskwie wystato kolejna, nowa kartę Stomoniakowa. Pisze o tym chargé d'affaires poselstwa w Moskwie Jan Karszo-Siedlecki w piśmie do MSZ DDP z 21 VI 1932 r. w: MSZ, sygn. 122a, k. 180. Nie udato się odnaleźć dokumentu.

Jest to jeden ze stabiej opracowanych biogramów. Stomoniakow (1882-1941) byt bardzo wytrawnym i antypolsko nastawionym dyplomata. Po-

28 Chodzi o Wydział Państw Nadbałtyckich i Polski. 
selstwo polskie w Moskwie chyba dtugo nie zdawato sobie z tego sprawy. Być może dyplomata Leonid Krasin odegrat pewna role w karierze Stomoniakowa, ale należy wymienić przede wszystkim Litwinowa. To właśnie on wprowadzit go do Ludowego Komisariatu Spraw Zagranicznych.

\section{Dokument 5}

k. 10. Mieczysław Loganowski, syn Antoniego, Naczelnik Wydziału Prybałtyki i Polski w Narkomindiele od listopada 1925 r.

Liczy około 40 lat i jest polakiem $\mathrm{z}$ b. zaboru rosyjskiego. W wojnie polsko-sowieckiej brał udział jako podpułk. sow. i dokonywał bezprawnych „rekwizycyj” w Nieświeżu. Został ranny i pełnił już dalej służbę w głównym biurze GPU (czeki) w Moskwie. W chwili reorganizacji tego urzędu policyjnego razem z innemi urzędnikami b. wyrobionemi, których delegowano zależnie od kwalifikacji do różnych komisarjatów, przydzielony został do Kom. Spr. Zagr. Był następnie urzędnikiem Poselstwa w Warszawie oraz Wiedniu. Naraził się wówczas propagandą i agitacją naszym władzom, które odmówiły mu nawet wizy tranzytowej (vide raport Pos. No. 985/T/25 z dn. 12 listopada 1925 r.).

Łoganowski nie posiada utrwalonej sytuacji w Narkomindiele i podobno nie cieszy się specjalnemi sympatjami polskich komunistów na urzędowych stanowiskach SSSR, jakkolwiek odgrywa w tych kołach stosunkowo poważną rolę.

Policyjna przeszłość wpłynęła zasadniczo na charakter i metody postępowania Łoganowskiego, który pnąc się po szczeblach hierarchii sowieckiej myślał przede wszystkim tylko o swej karjerze i etyką się nie krępował. Ambicje jego przewyższają znacznie zarówno zdolności, jak i powierzchowne wykształcenie. Podstępny, niechętny, mściwy, zarozumiały zachował w dyplomacji sowieckiej metody, do których przywykł na poprzednim swym stanowisku. Człowiek o umysłowości rosyjskiej, podkreśla jednak swą przynależność do narodowości polskiej. Wielomówny wysuwa nieraz $\mathrm{w}$ rozmowach politycznych własne koncepcje, nieuzgodnione $\mathrm{z}$ wyższemi władzami, licząc na skompromitowanie łatwowiernego rozmówcy przez wydobycie odeń niedyskrecji lub pozornych choćby zobowiązań. Stosunek jego do urzędowych czynników polskich jest zasadniczo nieprzychylny. Nominacja jego na Nacz. Wydz. Prybałtyki i Polski w 1925 r. zaskoczyła niemile MSZ, jakkolwiek bezpośrednio przedtem w charakterze przewodniczącego delegacji sowieckiej do rokowań w Jampolu doprowadził do porozumienia. W stosunkach z Poselstwem zachowu- 
je nazewnątrz formy pseudo-przyjacielskie i grzecznościowe, jakkolwiek nawet przy załatwianiu drobniejszych spraw bywa opornym i nieustępliwym.

Nie posiada własnych, szerszych koncepcji politycznych i jest skrupulatnym wykonawcą polityki swej władzy wyższej, jednakże z pewnym odchyleniem na niekorzyść każdorazowego kontrahenta politycznego.

Komentarz: Jest to karta opracowana prawdopodobnie w 1927 r. W październiku 1932 r. poselstwo w Moskwie wystało kolejna, nowa karte Łoganowskiego z numerem 124. Pisze o tym Patek $w$ piśmie do MSZ DDP z 18 X 1932 r. w: AAN, MSZ, sygn. 122a, k. 187. Nie udało się odnaleźć dokumentu.

Jest to dość dobrze opracowany biogram Łoganowskiego (1895-1938), który $w$ l. 1921-1923 byt sekretarzem potpredstwa sowieckiego $w$ Warszawie, ale $w$ rzeczywistości kierowat rezydentura wywiadu sowieckiego w Polsce). W l. 1925-1927 kierowat Wydziatem Państw Nadbaltyckich i Polski w LKSZ.

\section{Dokument 6}

k. 17. Michal Andrejewicz Karski, zast. Naczelnika Wydz. Prybałtyki i Polski w Narkomindiele.

Liczy 30 kilka lat, żonaty, dbały o poprawne stosunki rodzinne. Wszedł do Narkomindiełu z powołania, by służyć w tej formie idei rewolucyjnej. Poza urzędem oddaje się chętnie oświatowej robocie partyjnej. Był w Poselstwie Sowieckim w Warszawie referentem prasowym i zapoznał się gruntownie ze sprawami polskiemi i bałtyckiemi.

Jako ideowy komunista posiada zaufanie czynników partyjnych.

W urzędowaniu spokojny, ostrożny, dokładny, pracowity, przestrzegający ściśle zarządzeń przełożonych. Karski uchodzić może za dodatni typ dyplomaty sowieckiego. Posiada dużą skalę zainteresowań i stale powiększa zasób swych wiadomości. Jest wedle wszelkiego prawdopodobieństwa żydem z pochodzenia, jednakowoż nie posiada żydowskich cech charakteru i usposobienia. Zająć może z czasem odpowiedzialne stanowisko dyplomatyczne. Odznacza się prostotą i osobistą bezinteresownością.

Karski należy do tej grupy intelektualnych komunistów, na służbie państwowej sowieckiej, którym obcy jest imperjalizm rosyjski. Osobiście wierzy on w możność pacyfikacji stosunków polsko-sowieckich i rozumie doniosłość utrwalenia pokoju na zachodniej granicy Związku dla przyszłości i rozwoju Państwa Rewolucyjnego. Z urzędowania w Warszawie wy- 
niósł Karski dodatnie wspomnienia, doświadczenie pracy politycznej nad zagadnieniami polskiemi [od 1922 r.] wywołały w nim jednak pewne wątpliwości, do możności osiągnięcia celu, jaki uznał za jedynie właściwy.

Odnosi się krytycznie do Niemiec jako do mocarstwa imperjalistycznego i narodu o wybitnie burżuazyjnej i nacjonalistycznej psychologji. Zabezpieczenie przyszłości Państwa Rewolucyjnego widzi w ugruntowaniu wpływów sowieckich na wschodzie i sądzi, że dopiero potem Związek wzmocniony gospodarczo i ludnościowo, będzie mógł przystąpić do ekspansji na zachód w celach rewolucyjnych, nie zaś zaborczych.

Komentarz: Jest to karta opracowana i nadestana w 1927 r. przez Konsulat Gen. RP w Tyflisie do poselstwa w Moskwie. W październiku 1932 r. poselstwo w Moskwie wystato kolejna, nowa kartę Karskiego z numerem 112. Pisze o tym Patek w piśmie do MSZ DDP z 18 X 1932 r. w: AAN, MSZ, sygn. 122a, k. 187. Nie udało się odnaleźć dokumentu.

Jest to dość dobrze opracowany biogram Karskiego (1900-1937), który w l. 1923-1925 pracowat $w$ biurze prasowym potpredstwa $w$ Warszawie, $w$ rzeczywistości byt rezydentem sowieckiego wywiadu wojskowego, w l. 1925-1929 pracowat w Wydziale Państw Nadbałtyckich i Polski.

\section{Dokument 7}

\section{k. 53. Stalin /Dżugaszwili/ Józef, syn Wisarjona - Sekretarz Generalny} Partji Komunistycznej

2. Urodził się w $1879 \mathrm{r}^{29} \mathrm{w}$ mieście Gori gub. Tyfliskiej, syn szewca. W 1893 r. $^{30}$ ukończył szkołę parafjalną w Gori, poczem wstąpił do Tyfliskiego seminarjum duchownego, które było ogniskiem ruchu wyzwoleńczego gruzińskiego tak partyjno-narodowego, jak i socjalistyczno-internacjonalistycznego ${ }^{31}$. Stalin staje na czele kółek młodzieży, ulegającej wpływom marksyzmu. W 1898 r. wstępuje do partji socjaldemokratycznej i zbliża się z Kurnatowskim, pierwszym krzewicielem idei Lenina w Kraju Zakaukaskim; przez niego zbliża się z Leninem. W 1901 roku Stalin wobec rozgromienia Tyfliskiego Komitetu partji - zmuszony jest ukrywać się przed „ochraną” carską i aż do 1917 r. pracuje konspiracyjnie pod różnemi pseudonimami „Dawid”, „Koba”, „Niżeradze”, „Czyżyk”, „Iwanowicz”

29 Data urodzin Stalina budzi kontrowersje. W literaturze występują daty 1878 i 1879.

30 W literaturze funkcjonuje data 1894 ukończenia szkoły prawosławnej.

31 W seminarium obowiązywała surowa dyscyplina. Budziło to opór części wychowanków, którzy - jak oceniały władze seminarium - czytali „demoralizujące lektury”. Niektórzy biografowie Stalina przypuszczają, że pobyt tam ukształtował cechy przyszłego dyktatora. 
i „Stalin”. W ciągu tego okresu Stalin był kilkakrotnie aresztowany i skazywany na zesłanie; w 1903. na Syberję do Irkuckiej gubernji, w 1908 r. do gub. Wołogrodzkiej; w 1910 r. znów do gub. Wołogrodzkiej, w 1912 r. do kraju Narymskiego. Z miejsc zesłania Stalinowi zawsze udawało się w krótkim czasie uciekać i dopiero po aresztowaniu w 1913 r. Stalin przesiedział aż do 1917 r. na zesłaniu w Turuchańskim Kraju. Przez cały okres pracy konspiracyjnej Stalin rozwijał bardzo energiczną działalność z początku w Gruzji, następnie w Azejbaidżanie [Baku], wreszcie w Petersburgu, redagując kolejno cały szereg pism partyjnych i biorąc udział po stronie bolszewickiej w zaciekłej polemice $\mathrm{z}$ mienszewikami; reprezentuje też obóz bolszewicki na zjazdach partyjnych zagranicą w Sztokcholmie [1906 r.] w Londynie [1907 r.] w Krakowie [1912 r.], przyczem pracuje w bardzo bliskim kontakcie z Leninem. Po wybuchu rewolucji lutowej 1917 r. Stalin wraca do Piotrogrodu rzuca się w wir pracy rewolucyjnej i występuje stale jako najbliższy stronnik i pomocnik Lenina. W czasie rewolucji październikowej Stalin wybrany zostaje przez Centralny Komitet Partji jako członek ,piątki”, której polecono polityczne kierownictwo powstaniem oraz jako członek ,siódemki” kierującej organizacją powstania. Od 1917 r. Stalin jest członkiem Centralnego Komitetu Wykonawczego Sowietów. Jednocześnie od 1917 do 1923 r. był Komisarzem Ludowym do spraw narodowościowych, a od 1919 r. do 1923 r. Komisarzem Ludowym Robotniczo-Włościańskiej Inspekcji. W akcji zbrojnej sowietów Stalin brał bardzo żywy udział. W 1918 r. organizuje obronę Carycyna przed wojskami Krasnowa i przeprowadza razem z Dzierżyńskim inspekcję frontu 3-ej armji w pobliżu Permi. W 1919 r. pracuje na froncie Piotrogrodzkim, organizując kont-akcję przeciwko ofenzywie Judenicza, jak również w Smoleńsku przeciwko ofenzywie polskiej, bierze też udział w rozgromieniu wojsk Denikina. W 1920 r. w czasie wojny polsko-sowieckiej Stalin prowadzi akcję organizacyjną na froncie ukraińskim. Stalin jest członkiem Rady wojennej Z.S.S.R. Za zasługi wojenne otrzymał order Czerwonego Sztandaru.

3. Stanowisko Stalina w partji komunistycznej jest bardzo wpływowe. Od 1922 r. jest jednym z sekretarzy Centralnego Komitetu Partji, a od 1925 r. jest członkiem Prezydjum Kom. Wykonawczego Kominternu. Stalin był zawsze i pozostał dotychczas prawowiernym zwolennikiem Lenina, z którym pracował zdawna w bardzo bliskim kontakcie. W czasach rewolucyjnych i po ustaleniu się rządów sowieckich stawał zawsze w partji w obronie tez Lenina, zwalczając powstającą opozycję. Stalin jest zawsze centralistą i był jednym z inicjatorów okupacji Gruzji przez bolszewików. Po sowietyzacji Kaukazu otrzymał nominację na stanowisko odpo- 
wiedzialnego sekretarza Zakrajkowa, będąc jednocześnie członkiem Rady Rewolucyjnej Specjalnej armji Kaukaskiej [Osobaja Kawkaskaja Armja].

4. Stalin uchodzi za niezwykle zdolnego, rzutkiego i energicznego człowieka, co zresztą potwierdzają przytoczone powyższe dane z jego życia. Należy on bezprzecznie do kategoryj ideowych działaczy starszej generacji bolszewików fanatycznie oddanych sprawie, której służy. Horyzont myślowy wobec długotrwałej pracy nad sobą i podróży zagranicznych ma oczywiście znacznie szerszy od domorosłych bolszewików, w szczególności zaś od młodszej generacji karierowiczów partyjnych; ujawnia się to w całym szeregu ogłoszonych przez Stalina prac publicystycznych, dotyczących zagadnień aktualnych z dziedziny ekonomicznej i politycznej, w których przeważają problemy narodowościowe i kwestje prądów w łonie partii komunistycznej.

Komentarz: Jest to tekst nadesłany z Konsulatu Generalnego RP w Tyflisie z dn. 30 VII 1927 r. Prawdopodobnie rację ma A. Pepłoński, że ,pierwsza karta informacyjna dotyczaca Stalina została sporzadzona na poczatku lutego 1932 r.", A. Pepłoński, Wywiad a dyplomacja II Rzeczypospolitej, Toruń 2004, s. 110. Nie znamy jednak tej wersji z $1932 \mathrm{r}$.

Zaprezentowany tekst zawiera dużo informacji, ale stanowity one niewątpliwie tylko punkt odniesienia dla pracowników poselstwa w Moskwie, a szczególnie dla Stanisława Patka. Wprawdzie nie udało się odnaleźć karty z 1932 r., ale $w$ raportach posta Patka oraz jego wspótpracowników znajdujemy bardzo dużo informacji na temat Stalina. Opisano bardzo szczegółowo proces walki Stalina z opozycja w 1927 r., jego rolę w Biurze Politycznym KC WKP(b), dyktatorskie metody rząów.

\section{Streszczenie}

Polskie Ministerstwo Spraw Zagranicznych w okresie międzywojennym posiadało najprawdopodobniej ogromną dokumentację biogramów nie tylko dyplomatów z innych państw, ale także osób ze świata polityki, gospodarki, wojskowości i zapewne innych dziedzin. W artykule został uwzględniony niewielki tylko fragment dokumentacji wytworzonej przez poselstwo RP w Moskwie w 1927 r., znajdujący się w Archiwum Akt Nowych. W kontekście omawianej tematyki najważniejszy był Departament Polityczno-Ekonomiczny polskiego MSZ, gdyż to tam został zainicjowany proces zbierania danych osobowych i tam dane te były gromadzone. Po 1932 r. jego znaczenie uległo zmniejszeniu na rzecz Gabinetu Ministra. Zapewne po 1932 r. to Gabinetowi podlegały sprawy kart informacyjnych. Praca nad biogramami, czyli kartami informacyjnymi poszczególnych osób przebiegała 
dwutorowo: na placówkach dyplomatycznych i w centrali, czyli w Departamencie Politycznym. Karty te miały charakter otwarty, to znaczy, że były uzupełniane przez centralę, ale przede wszystkim przez placówki dyplomatyczne i to one włączały je do Skorowidza Informacyjnego. Zaprezentowane biogramy 7 dyplomatów i polityków sowieckich stanowią fragment dokumentacji znajdującej się w AAN w zespole Ambasada RP w Moskwie, sygn. 36. W teczce tej na kartach 5-53 przedstawiono biogramy 48 osób, w tym głównie dyplomatów i polityków, ale także wojskowych, osób powiązanych z gospodarką. Wybór $7 \mathrm{z}$ nich wynikał ze znaczenia tych postaci dla spraw polskich i stosunków polsko-sowieckich, chociaż jest oczywiście subiektywny. Wybrane dokumenty, a przede wszystkim lektura tych zdeponowanych w Archiwum Akt Nowych, wskazują na dużą wiedzę i profesjonalizm polskiej dyplomacji w gromadzeniu danych na temat sowieckiej dyplomacji, chociaż w biogramach tych występują także braki. 